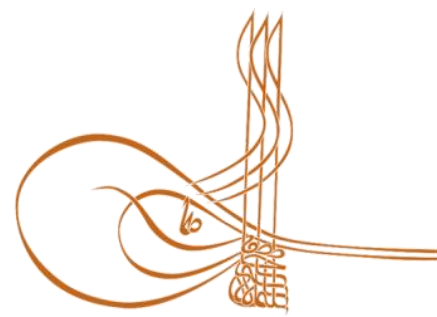

www.turkishstudies.net/economy
Turkish Studies - Economics, Finance, Politics

eISSN: $2667-5625$

Research Article / Araștırma Makalesi

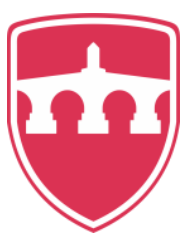

INTERNATIONAL BALKAN

UNIVERSITY

Sponsored by IBU

\title{
Tüketicilerin Paylaşım Ekonomisine Katılmalarına Etki Eden Paylaşım Engelleri ve Farklı Paylaşım Durumları
}

\author{
The Sharing Barriers and Different Sharing Situations That Affect Consumers' Participation in the \\ Sharing Economy
}

\author{
Volkan Yakın*
}

\begin{abstract}
Sharing economy, as a result of the technological advantages and social interactions offered by the present age, is a system involving more and more consumers but still observed that a significant number of consumers stay away from the system. Knowing the barriers to participation in the sharing economy, which provides an important advantage in terms of sustainability, is important in terms of taking measures to eliminate these barriers. There are various preventive factors such as risk perception and security factors that affect participants' stay away from the system. On the other hand, consumers' intention to share in different sharing situations may also vary. In this study, firstly, the effects of the factors (materialist tendencies, fear of transmission, risk perception and security) which are thought to prevent participation in the sharing economy were determined. In addition, a scenario-based quantitative study was conducted on six groups in three different categories in order to determine the participants' intention to share in different sharing situations (personal product sharing and non-personal product sharing; shares in which consumption action occurs and does not occur together; paid and non-paid sharing). As a result of the study, it was determined that risk perception, security concerns and fear of transmission showed a significant difference negative effect on sharing intention. However, the materialist tendencies of the participants and the status consumption tendencies could not have a negative effect on the sharing intentions. It was also determined that the paid and unpaid cases for the sharing action had a significant effect on the sharing intention.
\end{abstract}

Structured Abstract: Sharing economy is a concept that has formed a common cluster in the research of various disciplines from sociology to marketing in recent years. Since scientists from different disciplines handle the concept of sharing economy from different perspectives, there is no single definition that has been agreed upon. Yakın (2018), who, like many other authors working on this subject, approaches the sharing economy in terms of sustainability and emphasizes that sharing economy formations should not enter the wheel of the capitalist system. It is defined as the innovative formations that are created by the initiatives of individuals or organizations that want to share with people and contribute to sustainability while creating a destructive effect for some existing sectors ". For the sustainability of the system, knowing the obstacles to

\footnotetext{
* Dr. Öğr. Üyesi, Bolu Abant İzzet Baysal Üniversitesi, Gerede Uygulamalı Bilimler Yüksekokulu, Pazarlama Bölümü Asst. Prof. Dr. Bolu Abant Izzet Baysal University, School of Applied Sciences, Department of Marketing ORCID 0000-0001-6518-8348

volkanyakin@yahoo.com

Cite as/ Atıf: Yakın, V. (2020). Tüketicilerin paylaşım ekonomisine katılmalarına etki eden paylaşım engelleri ve farklı paylaşım durumları, Turkish Studies - Economy, 15(1), 595-612. https://dx.doi.org/10.29228/TurkishStudies.40129

Received/Geliş: 11 December/Aralık 2019

Accepted/Kabul: 25 March/Mart 2020

Copyright $($ INTAC LTD, Turkey
} 
participation in the sharing economy is important in terms of taking measures to eliminate these obstacles. Therefore, the reasons that prevent the consumers who stay away from the system as well as the motivation of participation of the consumers included in the system should be well known. In this study, the factors that prevent sharing are focused. These factors are materialism, perceived risk, safety, fear of contamination and status (conspicuous) consumption.

From a socio-cultural point of view, materialism refers to a culture in which the vast majority of people in the society highly value material assets, while individually, materialism refers to a person who highly values material assets (Larsen et al., 1999). Risk perception is defined as to what extent a person believes that uncertainty exists as to whether the desired results will be achieved (Mittendorf and Ostermann, 2017: 5828). Trust is defined as the desire of a person (buyer) to be vulnerable to another person (seller) based on the relationship between the buyer and seller (Neunhoeffer and Teubner, 2018; Dimoka, 2010). Conspicuous consumption is defined as the type of consumption based on the motivation process of strengthening the social positions of the person by conspicuously consuming the consumer products, which is the symbol of prestige (status) for the individual and other important people around him (Eastman et al., 1999,: 42). Fear of contagion is a fear that causes the obsession of cleaning, and people with this obsession try to overcome the fear of contamination by trying to avoid materials that they think will threaten their health (Rachman, 2004: 1227). Researches can also affect the consumption preferences of these motivations of individuals to protect themselves (Griskevicius \& Kenrick, 2013; Argo et al., 2006).

The purpose of this study is determining the factors that prevent individuals from participating in the sharing economy and the participants' sharing intentions in different sharing situations ("whether the sharing action is and does not happen together", "whether money is used in the sharing action" and "whether the shared item is a personal product"). In studies on sharing economy, it can seem that authors generally research the obstacles to participation in sharing economy with motivating factors. There are few studies addressing the issue only in terms of preventive factors, and more importantly, in the previous studies investigating the factors preventing participation in the sharing economy are mostly qualitative methods were used. Therefore, this study was carried out with the idea that quantitative researches on the subject should also be carried out.

In the research, scenario-based survey technique, which is one of the quantitative research methods and frequently used in consumer behavior research, was used. In order to determine the intention to share in different sharing situations, a total of 6 scenarios were prepared under 3 categories. In the research, 635 students were reached at Abant Izzet Baysal University. The number of samples was divided into six and an average of 105 questionnaires were applied to each group to evaluate scenarios for different sharing situations. While preparing the scale of the research, Akbar et al. (2016) for materialism, Golsmith and Clark (2012) for status consumption, So et al. (2018) for risk perception and security, Burns et al. (1996) for fear of contamination studies has been benefited. The questionnaire form prepared as a 5-point Likert scale $(1=$ strongly disagree / $5=$ strongly agree) was used to determine the students' participation in the statements.

A total of 26 expressions in the scale were first subjected to a reliability test, and low-reliability expressions were excluded from the analysis. As a result, the cronbah's alpha value of 23 expressions in the scale was 78.6 in the $95 \%$ confidence interval. This value is above the minimum level of 0.70 which is deemed necessary for the scale to be reliable (Kurtuluş, 2010: 184). Structural equation model path analysis test was used to analyze the hypotheses to determine the relationships between the factors. As a result of the hypothesis tests, the hypotheses of H2 (The perceived risk affects the sharing intention significantly.), H3 (The lack of trust affects the sharing intention significantly) and H5 (The fear of contagion affects the sharing intention significantly). H1 (Materialism negatively affects sharing intention significantly) and H4 (Status consumption negatively affects sharing intention significantly) hypotheses were rejected. As a result of the T test, while the H6a (Sharing intention of the participants differs significantly in the case of sharing personal and non-personal products) and H6b (Participants' sharing intentions differ significantly when the sharing action occurs and does not occur together.) hypotheses were rejected, the H6c (Participants' sharing intention in paid and non-paid sharing situations differs significantly) hypothesis was accepted.

As a result of this study, company managers or new entrepreneurs who want to join the sharing economy system are recommended to consider the factors that will eliminate the perceptions of risk, security and contamination fears of consumers in both product and service designs and marketing communication studies. In addition, for the target audience, it is suggested to observe the factors that affect the intention to share in different sharing situations.

Turkish Studies - Economy, 15(1) 
Keywords: Sharing economy, Sharing barriers, Risk perception, Contamination fear

Öz: Paylaşım ekonomisi, içinde bulunduğumuz dijital çağın sunduğu teknolojik avantajlar ve sosyal etkileşimler sonucunda giderek daha fazla tüketicinin dâhil olduğu bir sistem olmakla birlikte önemli sayıda tüketici kitlesinin sistemden uzak durduğu gözlenmektedir. Sürdürülebilirlik açısından önemli bir avantaj sağlayan paylaşım ekonomisine katılımın önündeki engellerin bilinmesi, bu engelleri ortadan kaldıracak önlemlerin alınması açısından önem taşımaktadır. Katılımcıların sistemden uzak durmasına etki eden risk algısı ve güvenlik faktörleri gibi çeşitli engelleyici faktörler bulunmaktadır. Diğer taraftan tüketicilerin farklı paylaşım durumlarında paylaşma niyetleri de farklılık gösterebilmektedir. Bu çalışmada öncelikle paylaşım ekonomisine katılımı engellediği düşünülen faktörlerin (materyalist eğilimler, bulaşma korkusu, risk algısı ve güvenlik) paylaşma niyetine olan etkisi belirlenmiştir. Ayrıca farklı paylaşım durumlarında katılımcıların paylaşım niyetlerini belirlemek üzere üç farklı kategoride (kişisel ürün paylaşımı ve kişisel olmayan ürün paylaşımı; tüketim eyleminin birlikte gerçekleştiği ve birlikte gerçekleşmediği paylaşımlar; paylaşım için ücret ödenen ve ücret ödenmeyen paylaşım durumları olmak üzere) toplamda altı grup üzerinde senaryo temelli nicel bir araştırma yürütülmüştür. Araştırma sonucunda risk algısının, güvenlik kaygılarının ve bulaşma korkusunun paylaşım niyeti üzerinde negatif yönde anlamlı bir farklılık gösterdiği belirlenmiştir. Bununla birlikte katılımcıların materyalist eğilimleri ve statü tüketim eğilimlerinin paylaşım niyetleri üzerinde negatif bir etkisi görülememiştir. Ayrıca paylaşım eylemi için ücret ödenen ve ödenmeyen durumların paylaşım niyeti üzerinde anlamlı bir etkisi olduğu belirlenmiştir.

Anahtar Kelimeler: Paylaşım ekonomisi, Paylaşım engelleri, Risk algısı, Bulaşma korkusu

\section{Giriş}

Kökleri avcı toplayıcı döneme dayanan paylaşım ekonomisi, günümüz tüketim davranışının da önemli bir parçasını oluşturmaktadır. Son yirmi yılda ortaya çıkan teknolojik gelişmeler ve web 2.0 uygulamalarının kullanımının yaygınlaşmasıyla birlikte paylaşım ekonomisinin de çeşitli sektörlerde yaygınlaştığı görülmüştür. Paylaşım ekonomisi son yıllarda sosyolojiden, pazarlamaya çok çeşitli disiplinlerin araştırmalarında ortak kümeyi oluşturmuş bir kavramdır. Farklı bilim dallarından bilim insanlarının paylaşım ekonomisi kavramını farklı açılardan ele alması nedeniyle üzerinde uzlaşı sağlanmış tek bir tanım olmadığı gibi paylaşım ekonomisini ifade eden terimler de ortaklaşa tüketim, işbirlikçi tüketim, erişim temelli tüketim vb. çeşitli isimler almaktadır.

Literatürde paylaşım ekonomisinde en s1k karşılaşılan tanım konunun öncül araştırmacılarından olan Belk (2007)'e aittir. Belk (2007) paylaşım eyleminin ancak, karşılığında bir bedel ödenmediği yani ücretsiz bir şekilde gerçekleştiği takdirde gerçek bir paylaşım olacağ1 görüşünden hareketle paylaşım ekonomisi ile gerçekleşen değiş tokuşları mevcut alışveriş sisteminin bir alternatifi olarak değerlendirmiştir. Paylaşım ekonomisine yönelik gelişmelere daha çok tüketici davranışı açısından yaklaşan ve yoğun atıf alan bir diğer çalışmada Botsman ve Rogers (2010)'a aittir, yazarlar paylaşım ekonomisini ă̆ teknolojilerinin kullanılmasıyla birlikte daha önce görülmemiş ölçeklerde ve şekillerde ortaya çıkan paylaşım eylemleri olarak tanımlamışlardır. Bu konu üzerinde çalışan diğer bir çok yazar gibi paylaşım ekonomisine sürdürülebilirlik açısından yaklaşan ve paylaşım ekonomisi oluşumlarının kapitalist sistemin çarkına girmemesi gerektiğine vurgu yapan Yakın (2018) ise paylaşım ekonomisini "Web 2.0 ağ teknolojileri aracılığıyla elindeki atıl kaynakları maddi veya manevi bir karşılık elde etmek amacıyla diğer kişilerle paylaşmak isteyen kişi veya kuruluşların girişimleriyle ortaya çıkan ve sürdürülebilirliğe katkıda bulunurken mevcut bazı sektörler için de yıkıcı bir etki yaratan yenilikçi oluşumlar" olarak tanımlamaktadır.

Paylaşım ekonomisine ilişkin işletme ve pazarlama (tüketici davranışları) kapsamında birçok araştırma yapılmıştır (Lamberton ve Rose, 2012; Sundararajan 2014; Schor ve Fitzmaurice, 2015; Ertz vd., 2016; Hamari vd., 2016; Edbring vd., 2016; Gazzola vd., 2019; Yakın vd. 2017; Böcker ve Meelen, 2017; Zhu vd, 2017; Mahadevan, R. 2018). Bu çalışmaların bir kısmının kavramın 
tanımlanması yönünde teorik nitelikte olduğu görülürken büyük bir bölümünün de tüketicilerin paylaşım ekonomisine katılmalarına sebep olan motivasyon faktörlerinin araştırılmasına yönelik uygulamalı araştırmalar olduğu görülmektedir. Söz konusu faktörler araştırmalarda içsel ve dışsal motivasyon faktörleri olarak ele alınmaktadır. Haz/ keyif alma, sürdürülebilirlik içsel motivasyonları oluştururken, ekonomik fayda ve ün kazanma isteği paylaşım ekonomisinin dişsal motivasyonlarını oluşturmaktadır (Hamari vd.,2016). İçinde bulunduğumuz ve başta küresel 1sınma olmak üzere çevresel kaygıların zirveye ulaştığı çağda, sürdürülebilir tüketim davranışı kapsamında yer alan ve karbon salınımını azaltan ortak tüketim girişimlerinin çevresel sorunlara çözüm üretecek amaçlar etrafında yaygınlaşması oldukça önem kazanmaktadır bu nedenle tüketicilerin paylaşım ekonomisine dâhil olmalarına etki eden faktörlerin bilinmesi de bir o kadar önem taşımaktadır. Literatürde tüketicilerin paylaşım ekonomisine katılmalarını teşvik eden faktörleri belirlemeye yönelik oldukça fazla sayıda çalışma yapıldığı görülmekle birlikte bireylerin paylaşım ekonomisine katılmalarına engel olan faktörlere odaklanmış araştırmaların yetersiz kaldığı görülmüştür (Ozanne ve Balantine, 2010; Özata vd. 2015; Akbar vd., 2016).

Sistemin sürdürülebilirliği için paylaşım ekonomisine katılımın önündeki engellerin bilinmesi, bu engelleri ortadan kaldıracak önlemlerin alınması açısından önem taşımaktadır. $\mathrm{Bu}$ nedenle sisteme dâhil olan tüketicilerin katılım motivasyonları kadar sistemden uzak duran tüketicileri engelleyen nedenlerin de iyi bilinmesi gerekir. Bu çalışma kapsamında paylaşımı engelleyici faktörlere odaklanılmıştır. Bu faktörler materyalizm, algılanan risk, güvenlik, bulaşma korkusu ve statü (gösterişçi) tüketim faktörlerdir. Araştırma kapsamında faktörlerin tüketicilerin paylaşma niyeti üzerindeki etkileri incelenmiştir. Ayrıca paylaşım ekonomisi içerisinde "paylaşım için ücret ödeyip ödememe", "kişisel eşya veya kişisel olmayan eşya paylaşma" ve "tüketim eyleminin ödünç veren ile birlikte gerçekleşip, gerçekleşmesi” gibi farklı paylaşım durumlarının tüketicilerin paylaşma niyetine olan etkisi de araştırılmıştır.

\section{Literatür Taraması}

\section{Materyalizm}

Başlangıçta madde ve onun hareketleri dışında hiçbir şeyin var olmadığ 1 felsefi görüşüne dayanan materyalizm popüler kullanımda maddi ihtiyaçlara ve arzulara adanmışlığı, manevi yanın ihmal edilmesi ve tamamen maddi çıkarlar üzerine dayanan bir yaşam tarzı, görüş ya da eğilim olarak tanımlanmaktadır (Richins ve Dawson, 1992: 303-304). Belk (1984: 291) ise materyalizmi bir kişinin dünyevi sahipliklere verdiği önem olarak tanımlamıştır. Son yıllarda pazarlama ve tüketici davranışlarında önemi artan bir konu olan materyalizm genel olarak sosyo-kültürel ve bireysel perspektiften ele alınmıştır (Srikant, 2013:331). Sosyo-kültürel açıdan, materyalizm toplumdaki insanların büyük çoğunluğunun maddi varlıklara yüksek derecede değer verdiği bir kültürü ifade ederken bireysel açıdan ise, materyalizm, maddi varlıklara yüksek derecede değer veren kişiyi ifade etmektedir (Larsen vd., 1999). Bireysel perspektifte pazarlama alanında materyalizmin kavramsallaştırılmasında genel kabul görmüş değer olarak materyalizm ve bir kişilik özelliği olarak materyalizm olmak üzere iki ana teorik akım bulunmaktadır (Manchiraju ve Krizan, 2015: 90). Richins ve Dawson (1992: 304) materyalizmi bir değer olarak ele almış ve geliştirmiş olduğu ölçeğinde materyalizmi merkeziyetçilik, mutluluk ve başarı olmak üzere üç faktör altında toplamıştır. Merkeziyetçilik faktörü maddi varlıklara sahip olmayı yaşamlarının merkezinde ne ölçüde yer aldığını ölçerken, mutluluk faktörü, insanların tatmini ve refahları için maddi varlıklara sahip olmanın ne ölçüde önemli olduğunu ölçmektedir. Başarı faktörü ise insanların kendi ve diğerlerinin başarısını sahip olunan maddi varlıkların sayısı ve kalitesine ne ölçüde bağladığını ölçmektedir. Belk (1984) ise materyalizmi bir kişilik özelliği olarak ele almış ve materyalizmi sahiplik, kıskançlık ve cimrilik olmak üzere üç faktör altında toplamıştır. Kıskançlık, bireylerin başka insanların sahip olduğu maddi varlıklara olan güçlü arzuyu ifade ederken, sahiplik, bireyin maddi varlıklara sahip 
olma ya da onları elinde tutma isteğini ifade eder. Cimrilik ise, bireyin sahip olduğu maddi varlıkları başkalarına vermeme, onlarla paylaşmamayı ifade etmektedir.

Günümüzde materyalist değer eğilimi, güncel tüketici kültürünün temelini oluşturmakta, satın alınan malların türünü, kalitesini ve onlara ayrılan ödeneği etkilemektedir (Ersoy-Quadir, 2012: 32). Materyalist değerleri yüksek seviyelerde olan kişiler için maddi varlıklara sahip olma hayatlarında merkezi bir yer tutmaktadır ve bu kişiler için sahip olma olgusu, tatmin olma ya da olmama durumunun en önemli kaynağıdır (Öztürk ve Öztay, 2019: 17). Materyalist insanlar kendilerini ve başkalarını sahip oldukları eşyalar ile tanımlarlar, mutluluk ve neşenin kaynağını tüketimde bulmaktadırlar (Karaca, 2019: 244). Materyalist bireyler bir şeylere sahip olmaya diğerlerine göre daha fazla değer verirler ve benmerkezci bir yapıları olup, hayattan daha az tatmin olurlar (Richins and Dawsons, 1992: 308). Ayrıca materyalizm düzeyi yüksek olan bireylerin arkadaşlarına ve akrabalarına borç para vermeye istekli olmaları ya da kişisel bir değer olarak başkaları ile sıcak iletişim kurmaları daha az olası görülmektedir. Materyalistlerin az paylaşımcı olmalarının nedeni ise nesnelere insanların üzerinde değer vermelerinden kaynaklanmaktadır (ErsoyQuadir, 2012: 32). Literatürde materyalizm ile paylaşım ekonomisi ve paylaşım niyeti arasındaki ilişki yapılan ampirik çalışmalarda araştırılmıştır (Akbar vd., 2016; Perfili vd., 2019; Belk 1984; Ozanne ve Ballantinne, 2010; Lindblom vd., 2018). Belk (1984) sahipliğe önem veren materyalist bireylerin ödünç alma ve kiralama yerine bir şeye sahip olmayı tercih ettiğini belirtmiştir. Belk (2010) ayrıca maddi varlıklara sahip olmanın materyalist insanlara mutluluk vermesinden dolay1 paylaşma içinde bulunmadıkları belirtmiştir. Ozanne ve Ballantine (2010) tarafından yapılan çalışmada, paylaşma eylemine katılan bireylerin materyalizm ölçeğinde nispeten daha düşük puanlar alındığ 1 ortaya konulmuştur. Lindblom vd. (2018) ise çalışmalarında materyalizmin, tüketicilerin işbirliğine dayalı (ortak) tüketim konusundaki tutumlarıyla olumsuz yönde ilișkili olduğunu bulgulamışlardır. Bir başka deyişle, materyalist olarak kabul edilebilecek tüketicilerin ortak tüketimi olumsuz bir davranış olarak algıladıkları belirlenmiştir. Akbar vd., (2016) materyalizmin sahiplik ve cimrilik boyutları ile ticari paylaşım sistemlerine katılım (paylaşım ekonomisine katılım) niyetini araştırdığı çalışmasında materyalizmin alt boyutları olan sahiplik ve cimrilik boyutlarının paylaşma niyetinde önemli engelleyici faktörler olduğu sonucuna ulaşmıştır. Akbar vd., (2016) ayrıca cimriliğin kişiler arasındaki paylaşmaya katılımının önünde bir bariyer olduğunu belirtmiştir. Perfili vd. (2019) sahiplik ve cimrilik boyutlarını ele alarak materyalizm ile paylaşma niyeti arasındaki ilişkiyi İtalyan ve İspanyol tüketiciler üzerinde araştırmışlardır. Yaptıkları çalışmada yüksek materyalist eğilimlere sahip bireylerin yüksek paylaşma niyeti göstermedikleri sonucuna ulaşmışlardır. Literatürde yapılan çalışmalardan görüldüğü üzere materyalizm ile paylaşımda bulunma ile negatif bir ilişki söz konusudur. Buna göre, materyalist bireyler maddi varlıklara sahip olmak istemekte ve paylaşım konusunda da cimri davranmaktadırlar. Dolayısıyla bu çalışmanın ilk hipotezi şu şekildedir:

H1 Materyalizm, paylaşma niyetini anlamlı derecede negatif yönde etkilemektedir.

\section{Risk Algısı}

Risk algısı, istenen sonuçların gerçekleşip gerçekleşmeyeceği konusunda bir kimsenin belirsizliğin var olduğuna ne ölçüde inandığ 1 şeklinde tanımlanmaktadır (Mittendorf ve Ostermann, 2017:5828). Algılanan risk teorisine göre, tüketiciler riski algılarlar; çünkü satın alımların sonucunda belirsizlik ve potansiyel olarak istenmeyen sonuçlarla karşı karşıya kalırlar (Lim, 2003: 218). Bauer (1960) çalışmasıyla pazarlama alanında yer almaya başlayan algılanan risk kavramı hizmet satın alma davranışlarında ve teknoloji kabul çalışmalarında önemli bir rol oynamaktadır. Paylaşım ekonomisi hizmetlerinin kullanımı da hem tüketici satın alma kararlarını hem de yenilikçi teknolojilerin kabulünü içermektedir (Hong, 2017: 2). Bu açıdan paylaşım ekonomisini inceleyen bu çalışmada algılanan risk değişkenini incelemek önem arz etmektedir. Literatürde paylaşım ekonomisi ve risk 
algısı değişkenleri arasındaki iliş̧inin incelendiği çalışmalar mevcuttur (Pavlou vd., 2007; Hong 2017; Ballus-Armet, 2014; Dillahund ve Malone, 2015; Hajli ve Lin, 2016).

Paylaşım ekonomisi sitelerine katılımda kullanıcıların detaylı kişisel bilgilerinin talep edilmesi kullanıcılar arasında başta gelen risklerden biri olarak görülmektedir. Bu durum da kişilerin paylaşım sistemlerine katılımı konusunda cesaretini kırmaktadır (Lee vd., 2016). Demirer ve Hassan (2016) yaptıkları çalışmada paylaşım ekonomisi sistemi olarak değiş-tokuş ve kiralama uygulamaları sunan platformlar üzerinde yaptıkları çalışmada günlük kiralık ev uygulamalarında hijyen, kişisel güvenlik, gürültü, ev sahipleri, site içindeki yorumların kullanıcıların algıladığı riskler olarak belirlemişlerdir. Ballus-Armet vd., (2014) ise kişilerarasında araba paylaşımı konusunda sigorta, güven, paylaşma korkusu gibi risklerin mevcut olduğunu ve bu risklerin paylaşım sistemine katılımda önemli bariyer teşkil ettiğini belirtmiştir. Hong (2017) araç paylaşım niyetinde algılanan riskin rolünü incelediği çalışmasında paylaşım ekonomisi hizmetlerinde kullanıcılardan kişisel bilgilerin alınmaması kişilerin kullanım faydalarını önemli derecede arttığ 1 sonucuna erişmiştir. Lee vd. (2016) yapmış oldukları özet bildiri de algılanan risk ile paylaşım tüketimine katılma niyetine arasında negatif ilişki olduğunu öneren hipotezler geliştirmiştir. Ayrıca paylaşım ekonomisinde yer alan hizmetlerin faaliyetleri web site, telefon uygulamaları gibi sistemler yoluyla internetten sürdürülmektedir. Yapılan çalışmalarda algılanan risk ile çevrimiçi faaliyetler arasında da negatif ilişki bulunmuştur (Hajli ve Lin, 2016; Pavlou vd. 2007). Dillahund ve Malone (2015) Uber gibi paylaşım ekonomisi hizmetlerinde detaylı kişisel bilgiler istendiğini, bu bilgilerin kullanıcıların algılanan riskini arttırdığını ve tüketicilerin paylaşım sistemlerine katılım niyetlerini negatif olarak etkilediğini belirtmiştir. Lee vd. (2018) Uber üzerinde yaptıkları çalışmada algılanan riskin önemli derecede negatif olarak paylaşım sistemine katılım niyeti etkilediği sonucuna ulaşmışlardır. Yapılmış çalışmalar algılanan risk ile paylaşım niyetini arasında negatif ilişki söz konusudur. Dolayısıyla bu çalışmanın ikinci hipotezi şu şekildedir:

H2: Algılanan risk paylaşma niyetini anlamlı derecede negatif yönde etkilemektedir.

\section{Güvenlik}

Paylaşım ekonomisinde güven kavramı, katılımcıların eyleme geçmesinde temel belirleyicilerden biri olarak ifade edilmektedir (Botsman ve Rogers, 2010). Güven, alıcı satıcı ilişkisi çerçevesinde, bir kişinin (alıcının) beklentilere göre hareket edeceğine dayanarak başka bir kişiye (satıcı) karşı savunmasız olma isteği şeklinde tanımlanmaktadır (Neunhoeffer ve Teubner, 2018; Dimoka, 2010). Möhlman (2015), güven faktörünün, katılımcıların paylaşım sistemi seçeneğinden tatmin olmasına pozitif yönlü bir etkisi olduğunu ancak paylaşım sisteminin tekrar kullanma olasılığına pozitif yönlü bir etkisi olmadığını bulgulamıştır. Özata vd. (2015) çalışmalarında güven eksikliğinin paylaşım ekonomisine katılımının önünde bir engel olduğunu ancak en önemli faktör olmadığını belirlemiş̧lerdir. Yine diğer bazı araştırma sonuçlarında da güven faktörünün paylaşım ekonomisine katılıma engel olan bir faktör olduğu görülmüş̧ür (Edbring vd., 2015; Tussyadiah ve Pesonen, 2018; So vd., 2018). Bu bilgiler ışığında H3 hipotezi geliştirilmiştir.

H3: Güven eksikliği paylaşım niyetini anlamlı derecede negatif yönde etkilemektedir.

\section{Statü (Gösterişçi) Tüketim}

Özellikle içinde yaşadığımız dijital çağda post modern tüketicilerin, ideal benliklerini yansıtmak amacıyla markalardan her zamankinden çok faydalandıkları görülmektedir. Bu anlamda gösterişçi tüketim bireyin ait olmak istediği ve aslında ait olduğu statü (sosyal sınıf) arasında bir köprü görevi görmektedir (Tosun ve Cesur, 2018). Gösterişçi tüketim kısaca "kişinin çevresine statüsünü veya prestijini göstermek amacı ile yaptığı alışverişler, şeklinde tanımlanmaktadır" (Güllülü vd., 2010:106). Gösterişçi tüketim, daha kapsamlı olarak kişinin birey ve çevresindeki diğer önemli kişiler için prestij (statü) sembolü olan tüketici ürünlerini dikkat çekici bir şekilde tüketerek sosyal konumlarını güçlendirme motivasyon sürecine dayanan tüketim şekli olarak tanımlanmaktadır 
(Eastman vd, 1999, :42 ). Bununla birlikte O'cass ve McEwen (2004), gösterişçi tüketim ve statü tüketim kavramlarının, literatürde sıklıkla aynı tanımlarla açıklanmasına karşın, aralarında ufak bir fark olduğunu belirtmektedir. Statü tüketimi, gösterişçi tüketimden ayıran statü tüketiminde tüketicilerin ürünleri gösteriş yapma amacıyla tüketip tüketmediklerinin net olmamasıdır. Yani tüketici için gösterişçi tüketimde tüketim eylemini diğerlerine göstermek amacı taşırken statü tüketiminde (bazı durumlarda) gösterişe gerek duymadan prestij sağlayan bir ürün/hizmete sahip olmak yeterli olabilmektedir. Özetle gösterişçi tüketimin statü tüketiminin bir alt kümesi olduğu söylenebilir.

Statü tüketim ve paylaşım eknomosi arasındaki ilişkileri araştıran az sayıda çalışma bulunmaktadır. Bazı araştırmacılar paylaşımcı yaşam şeklinin kendisini, bağımsızlığı yansıtan, gösterişçi tüketimin yeni şekli olarak değerlendirmişlerdir (Hwang ve Griffiths, 2017; Teubner ve Hawlitschek, 2018). Bu bakış açısıyla Teubner vd. (2018) yürüttükleri araştırma sonucunda gösteriş̧̧i tüketimin paylaşım ekonomisine katılıma motive edici etkisi olduğunu belirlemişlerdir. Diğer taraftan Lawson vd.(2016) yürüttükleri araştırma sonucunda yüksek oranda statü tüketimi gerçekleştiren tüketicilerin paylaşım ekonomisine yönelik pozitif tutumlar sergilemelerine karşın bu hizmetlerden çok daha az faydalanmak istediklerini ortaya koymuştur. $\mathrm{Bu}$ araştırma kapsamında statü tüketim tüketilen ürün ve hizmetlerin çevredekilere yansıttıkları prestij açısından ele alınmaktadır bu nedenle motive edici değil engelleyici bir faktör olarak değerlendirilmektedir. $\mathrm{Bu}$ bilgiler 1şı̆̆ında statü tüketiminin paylaşım ekonomisine yönelik etkisinin daha net bir şekilde anlaşılabilmesi amacıyla $\mathrm{H} 4$ hipotezi geliştirilmiştir.

H4: Statü tüketimi paylaşma niyetini anlamlı derecede negatif yönde etkilemektedir.

\section{Bulaşma Korkusu}

Bulaşma, doğrudan veya dolaylı olarak, kirli, bulaşıcı veya zararlı olduğu algılanan bir kişi / yer / nesne ile temas sonucu doğrudan veya dolaylı olarak kirlenme, enfekte olma veya tehlikeye maruz kalma hissidir (Rachman, 2004:1229). Bulaşma korkusu ise temizlik takıntısının ortaya çıkmasına neden olan bir korkudur ve bu takıntıya sahip kişiler sağlıklarını tehdit edeceklerini düşündükleri materyallerden uzak durmaya çalışarak bulaşma korkularının üstesinden gelmeye çalışırlar (Rachman, 2004:1227). Yapılan araştırmalar, kişilerin kendilerini korumaya yönelik bu motivasyonlarının tüketim tercihlerine de etki edebilmektedir (Griskevicius ve Kenrick, 2013; Argo vd., 2006).

Lutz ve Newlands (2018), paylaşım ekonomisine dâhil olanların sınıflandırılmasına yönelik yaptıkları çalışmada tüketim eyleminin birlikte gerçekleştiği durumlarda tüketimin bağımsız gerçekleştiği paylaşım eylemlerine kıyasla tüketicilerin ortak eşyalara dokunma ve onları kullanma konusunda daha hassas oldukları bulgulamışlardır. Diğer taraftan Özata vd. (2015) çalışmalarında paylaşım eylemlerine dâhil olmak ve bulaşma korkusu arasında anlamlı bir ilişkiye rastlayamamışlardır. Bu bilgiler ışığında aşağıdaki hipotez belirlenmiştir.

H5: Bulaşma korkusu paylaşma niyetini anlamlı derecede negatif yönde etkilemektedir.

Araştırmanın son hipotezi ise farklı paylaşım durumlarında paylaşma niyetinin belirlenmesi şeklinde oluşturulmuştur;

H6: Farklı paylaşım durumlarında katılımcıların paylaşım niyetleri anlamlı farklılık göstermektedir.

H6a: Kişisel ürün ve kişisel olmayan ürün paylaşım durumlarında katılımcıların paylaşma niyeti anlamlı farklılık göstermektedir.

H6b: Paylaşım eyleminin birlikte gerçekleştiği ve gerçekleşmediği durumlara katılımcıların paylaşma niyetleri anlamlı farklılık göstermektedir. 
H6c Paylaşım eylemi için ücret ödendiği ve ödenmediği durumlarda katılımcıların paylaşım niyeti farkl1lık göstermektedir.

Geliştirilen hipotezler doğrultusunda araştırma modeli şekil 1'de gösterilmiştir.

Şekil 1: Araştırmanın Modeli

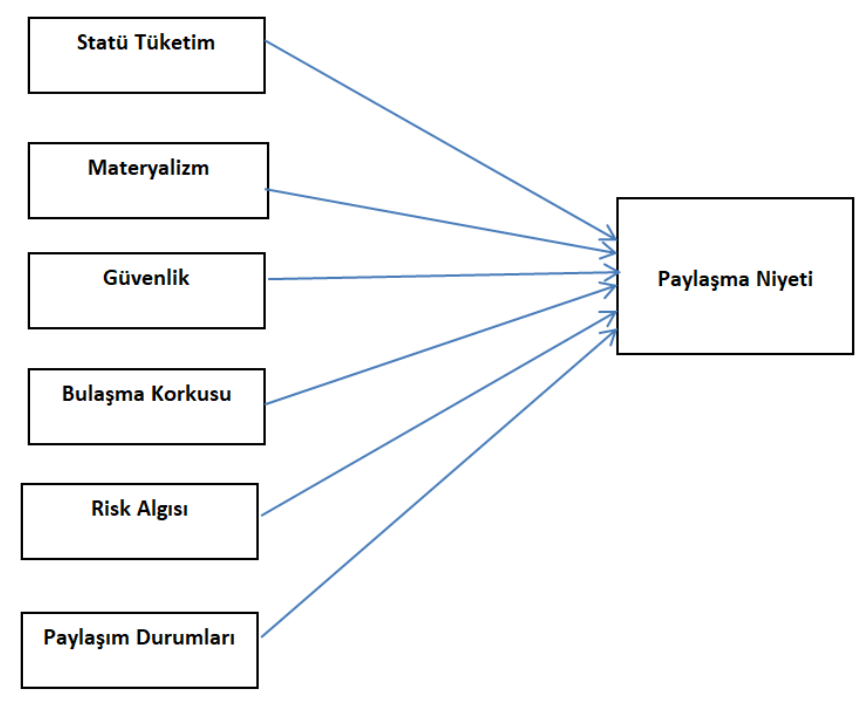

\section{Metodoloji}

\section{Araştırmanın Amacı ve Yöntemi}

$\mathrm{Bu}$ çalışmanın amacını, bireylerin paylaşım ekonomisine dâhil olmasına engel olan faktörlerin belirlenmesi ve farklı paylaşım durumlarında ("paylaşım eyleminin birlikte gerçekleştiği ve gerçekleşmediği", "paylaşım eyleminde para kullanılıp kullanılmadı̆̆ı" ve "paylaşılan eşyanın kişisel bir ürün olup olmadığı") katılımcıların paylaşım niyetleri arasında bir farklılık olup olmadığının belirlenmesi oluşturmaktadır. Paylaşım ekonomisi üzerine yapılan çalışmalarda yazarların genellikle paylaşım ekonomisine katılımın engellerini, motive edici faktörlerle birlikte kısmen araştırdıkları görülmüştür. Konuyu kapsamlı biçimde yalnızca engelleyici faktörler açısından ele alan az sayıda çalışma olması ve daha önemlisi paylaşım ekonomisine katılıma engel olan faktörleri araştıran önceki çalışmalarda çoğunlukla nitel yöntemler kullanılmış olması nedeniyle konuyla ilgili nicel araştırmalarında yapılması gerekliliği düşüncesiyle bu araştırma yapılmıştır.

Araştırmada nicel araştırma yöntemlerinden biri olan ve tüketici davranışları araştırmalarında sıklıkla kullanılan senaryo temelli anket tekniği kullanılmıştır. Farklı paylaşım durumlarında paylaşım niyetini belirlemek amacıyla 3 kategori altında toplam 6 senaryo hazırlanmıştır ${ }^{1}$. Araştırma

\footnotetext{
${ }^{1}$ Senaryo 1a: Yeni bir eve taşındığınızı ve bu evde musluk, mobilya montaj işlerinizi kendiniz yapacağınızı varsayın. İnternetten bu işlemler için gerekli tamir aletleri ararken bir internet sitesi üzerinden kişisel tamir aletlerini düşük bir ücret karşılığı paylaşmak isteyen amatör insanların ilan verdiğini görüyorsunuz. Hizmetten faydalanabilmek için kişisel bilgilerinizden oluşan bir formu web sayfası üzerinde doldurup sisteme kayıt olmanız gerekiyor.

Senaryo1b: Şehir dışına arkadaşınızı ziyarete gittiğinizi varsayın, arkadaşınız o gün önemli bir etkinliğe gidecek ve sizin de kendisine katılmanızı istedi. Ancak etkinlik için giyecek kıyafetiniz yok. Siz de internetten kıyafet araştırırken bir internet sitesi üzerinde kullanılmış kıyafetlerini düşük bir ücret karşıllğı paylaşmak isteyen insanların ilan verdiğini görüyorsunuz. Hizmetten faydalanabilmek için kişisel bilgilerinizden oluşan bir form doldurup sisteme kayıt olmanız gerekiyor.
} 
yapısı gereği homojen bir örneklem gerektirdiği için Gerede Uygulamalı Bilimler Yüksekokulu öğrencileri örneklem olarak seçilmiştir Okulun 1034 öğrencisi bulunmaktadır. Örneklem sayısının belirlenmesinde $\mathrm{N} \geq 1000$ olduğunda, $\% 95$ güvenlik düzeyinde $\mathrm{n}=278$ birim yeterli sayılmaktadır (Sekaran, 2003: 294). Araştırmada 635 öğrenciye ulaşılmıştır. Araştırmada örneklem sayısı altıya bölünmüştür ve her bir gruba farklı paylaşım durumlarına ilişkin senaryoları değerlendirmeleri için ortalama 105 'er anket uygulanmıştır. Araştırmanın ölçeği hazırlanırken materyalizm için Akbar vd.'nin (2016), statü tüketim için Golsmith ve Clark'ın (2012), risk algısı ve güvenlik için So vd.'nin (2018), bulaşma korkusu için Burns vd., (1996)'nin çalışmalarından faydalanılmıştır. Öğrencilerin ifadelere katılımını belirlemek amacıyla 5'li likert ölçeği $(1=$ kesinlikle katılmıyorum/5=kesinlikle katılıyorum) şeklinde hazırlanan anket formu ön test için 25 kişiye doldurtulduktan sonra gerekli kontrol ve düzeltmeler sonrasında öğrencilere uygulanmıştır. Toplanan verilerin analizinde SPSS paket programı kullanılmıştır.

\section{Araştırmanın sınırları ve kısıtları}

Araştırmanın zaman ve maliyet kısıtları nedeniyle sadece Abant İzzet Baysal üniversitesi öğrencileri üzerinde yürütülmüş olması sonuçların genellenmesini sınırlamaktadır bununla birlikte araştırmadan elde edilen sonuçlar farklı paylaşım durumlarında paylaşım ekonomisine katılıma engel olan faktörlere ilişkin önemli ipuçları vermektedir.

\section{Analiz ve Bulgular}

Ölçekte yer alan toplam 26 ifade öncelikle güvenilirlik testine tabi tutularak, güvenilirlik düzeyi düşük olan ifadeler analizden çıkarılmıştır. Sonuç olarak ölçekte yer alan 23 ifadenin cronbah's alpha değeri \%95 güven aralığında 78,6 çıkmıştır Bu değer ölçeğin güvenilir olması için gerekli görülen 0.70'lık minimum düzeyin üzerindedir (Kurtuluş, 2010:184). Tablo 1 KMO değerinin \%50'nin üzerinde ve Barlett Sphericity'nin anlamlı çıkması örneklem büyüklügünün faktör analizi için uygun olduğunu göstermektedir (Kalaycı, 2014). Tablo 2'de paylaşım engelleri ölçeğine ait faktörlerin geçerlilik ve güvenilirlik analiz sonuçları görülmektedir. Faktörler toplam varyansın \%62,408'ini açıklamaktadır.

Tablo 1: KMO ve Barlett's Test

\begin{tabular}{|l|l|r|}
\hline KMO &, 820 \\
\hline Bartlett's Test of Sphericity & Approx. Chi-Square & 6053,510 \\
\cline { 2 - 3 } & Sig. &, 000 \\
\hline
\end{tabular}

\footnotetext{
Senaryo 2a: Şehir dışına çıktığınızı varsayın ve kalacak yere ihtiyacınız var internet üzerinde konaklayacak bir yer ararken bir internet sitesi üzerinde sizi ücretsiz bir şekilde kendi evinde ağırlamak isteyen insanların ilan verdiğini görüyorsunuz. Hizmetten faydalanabilmek için kişisel bilgilerinizden oluşan bir form doldurup sisteme kayıt olmanız gerekiyor.

Senaryo2b: Şehir dışına çıktığınızı varsayın ve kalacak yere ihtiyacınız var internet üzerinde konaklayacak bir yer ararken bir internet sitesi üzerinde ücret karşılığında sizi kendi evinde ağırlamak isteyen insanların ilan verdiğini görüyorsunuz. Hizmetten faydalanabilmek için kişisel bilgilerinizden oluşan bir form doldurup sisteme kayıt olmanız gerekiyor.

Senaryo3a: Şehir dışına çıktığınızı varsayın ve kalacak yere ihtiyacınız var. İnternet üzerinde konaklayacak bir yer arıyorsunuz ve bir internet sitesi üzerinde sizi düşük bir ücret karşıllğı evinin bir odasında ağırlamak isteyen kişilerin ilan verdiğini görüyorsunuz. Hizmetten faydalanabilmek için kişisel bilgilerinizden oluşan bir form doldurup, web sayfası üzerinden sisteme kayıt olmanız gerekiyor.

Senaryo3b: Şehir dışına çıkma planı yapıyorsunuz ve kalacak yere ihtiyacınız var internet üzerinde konaklayacak bir yer ararken bir internet sitesi üzerinde bir şekilde otel odasına kıyasla uygun bir ücret karşılığı tüm evini sadece sizin kullanımınıza (kendisi o süre boyunca o evde kalmayacak) sunmak isteyen kişilerin ilanlarını görüyorsunuz. Hizmetten faydalanabilmek için kişisel bilgilerinizden oluşan bir form doldurup sisteme kayıt olmanız gerekiyor.
} 
Tablo 2: Paylaşım Engelleri Ölçeğinin Güvenilirlik ve Geçerlilik Analizi Sonuçları

\begin{tabular}{|c|c|c|c|}
\hline Faktörler & $\begin{array}{l}\text { Faktör } \\
\text { Yükleri }\end{array}$ & $\begin{array}{c}\text { Toplam } \\
\text { Varyans \% }\end{array}$ & Cronbach'sAlpha \\
\hline Bulaș (hijyen) korkusu & & 60,619 & 0,747 \\
\hline \multicolumn{4}{|c|}{$\begin{array}{l}\text { Yabancıların ya da belirli kişilerin dokunduklarını bildiğim-0,748 } \\
\text { eşyalara dokunmakta zorluk çekerim. }\end{array}$} \\
\hline $\begin{array}{l}\text { Hastalık bulaşmasından korktuğum için genel (ortak } \\
\text { kullanılan) tuvaletleri kullanmaktan kaçınırım. }\end{array}$ & $-0,801$ & & \\
\hline $\begin{array}{l}\text { Hastalık bulaşmasından korktuğum için genel (ortak } \\
\text { kullanılan) koltukları kullanmaktan kaçınırım. }\end{array}$ & $-0,870$ & & \\
\hline Sembolik tüketim & & 36,618 & 0,783 \\
\hline Eğer prestij yansıtacaksa bir ürüne daha çok para öderim & 0,820 & & \\
\hline Ürünleri prestijimi yansıtmaları için satın alırım & 0,802 & & \\
\hline Prestij yansıtan yeni ürünlere ilgi duyarım & 0,830 & & \\
\hline $\begin{array}{l}\text { Bir ürünün prestijli olup olmaması beni ilgilendirmez. } \\
\text { Çıkarılıyor }\end{array}$ & 0,682 & & \\
\hline $\begin{array}{l}\text { Bir ürünün havalı bir görüntüsü varsa benim için o ürün } \\
\text { diğerlerinden daha değerlidir. }\end{array}$ & 0,496 & & \\
\hline Algılanan risk & & 65,818 & 0,812 \\
\hline $\begin{array}{l}\text { Bu hizmetin (konaklama, kıyafet, araç paylaşımı...) } \\
\text { ödediğim ücrete değip değmeyeceği belli değil }\end{array}$ & $-0,913$ & & \\
\hline $\begin{array}{l}\text { Bu hizmetin (konaklama, kıyafet, araç paylaşımı...) amaca } \\
\text { uygun olup olmadığı belli değil }\end{array}$ & $-0,778$ & & \\
\hline $\begin{array}{l}\text { Bu hizmetin (konaklama, kıyafet, araç paylaşımı...) iyi bir } \\
\text { imaj sunacağı belirsiz }\end{array}$ & $-0,784$ & & \\
\hline Güvenlik & & 21,642 & 0,911 \\
\hline $\begin{array}{l}\text { Bu hizmetin üye kayıt sistemi kişisel bilgilerimin } \\
\text { güvenliğini yeterince sağlamıyor olabilir }\end{array}$ & 0,767 & & \\
\hline $\begin{array}{l}\text { Bu hizmet, hizmet alanın kişisel bilgi güvenliğini yüksek } \\
\text { oranda sağlamıyor olabilir }\end{array}$ & 0,824 & & \\
\hline $\begin{array}{l}\text { Bu hizmet hizmet alanın can güvenliğini yüksek oranda } \\
\text { sağlamıyor olabilir }\end{array}$ & 0,851 & & \\
\hline Bu hizmeti kullanırsam emin ellerde olmayabilirim & 0,912 & & \\
\hline Bu hizmeti satın almak güvenli olmayabilir. & 0,870 & & \\
\hline Materyalizm (eli sıkılık) & & 53,851 & 0,712 \\
\hline Evimde misafir ağırlamak bana keyif verir & 0,863 & & \\
\hline Sahip olduklarımı paylaşmaktan keyif alırım & 0,869 & & \\
\hline Genel Paylaşma niyeti & & 46,761 & 0,774 \\
\hline $\begin{array}{l}\text { Bir ücret karşıllı̆ında eşyalarımı başkalarıyla birlikte } \\
\text { kullanmaya oldukça istekliyimdir }\end{array}$ & $-0,661$ & & \\
\hline $\begin{array}{l}\text { Tüketici ürünlerini bir ücret karş1llğında paylaşmak onlara } \\
\text { sahip olmaktan daha iyi bir alternatiftir. }\end{array}$ & $-0,716$ & & \\
\hline $\begin{array}{l}\text { Gelecekte satın almak yerine paylaşılan ürünleri daha çok } \\
\text { tercih edeceğim. }\end{array}$ & 0,765 & & \\
\hline $\begin{array}{l}\text { Tüketici ürünlerini satın almak yerine onları } \\
\text { kullanabilmenin alternatif yollarını tercih ederim. }\end{array}$ & 0,725 & & \\
\hline $\begin{array}{l}\text { Bir ücret karşllığında tüketici ürünlerini paylaşma } \\
\text { olasillğıım yüksektir. }\end{array}$ & $-0,708$ & & \\
\hline
\end{tabular}


Verilere uygulanan normal dağılım testi sonucunda verilerin normal dağılmadığı görülmekle birlikte normal dağ 1 lım testi sonucunda verilerin çarpıklık değerlerinin $+1 /-1$ aralığında olduğu anlaşılmaktadır. Literatürde çarpıklık değerinin $+1 /-1$ aralığında (bazı kaynaklarda çarpıklık ve basıklık değerinin $+2 /-2$ aralığında) olduğu durumlarda verilerin normal dağılım gösterdiği kabul edilerek verilerin parametrik testlerle analiz edilebileceği belirtilmektedir (Morgan vd., 2012: 51; Garson, 2012:18-19; Kalayc1, 2006: 6 ve 209).

Faktörlerin arasındaki ilişkileri belirlemeye yönelik hipotezlerin (H1a, H2a, H3a, H4a, H5a) analizi için yapısal eşitlik modeli yol analizi testinden faydalanılmıştır. Modelin uyum iyiliği değerlerine bakıldığında RMSA değerinin 0,005 ile iyi uyumu, RMR değerinin 0,09, GFI değerinin 0,91 , AGFI değerinin 0,89, CFI değerinin 0,93, NFI değerinin 0,90 ile kabul edilebilir uyum aralığında oldukları dolayısıyla modelin çalıştığı belirlenmiştir (Tablo 3) (İlhan ve Çetin, 2014: 31). Faktörler arasındaki ilişkilerin ölçülmesine yönelik düzenlenen yapısal eşitlik modeli Şekil 2'de görüldüğü gibidir.

Tablo 3: Yapısal Eşitlik Analizi Uyum Değerleri

\begin{tabular}{|c|c|c|c|}
\hline \multirow{2}{*}{ İndeks } & \multirow{2}{*}{ Değer } & $\begin{array}{c}\text { İyi } \\
\text { Uyum }\end{array}$ & Kabul Edilebilir Uyum \\
\cline { 3 - 4 } & & $\leq 2$ & $\leq 2-3$ \\
\hline$x^{2} / S D$ & 2,73 & $\leq 2,05$ & $0,06-1,00$ \\
\hline RMR & 0,09 & $\leq 0,05$ & $0,90-0,95$ \\
\hline GFI & 0,91 & $\geq 0,95$ & $0,85-0,89$ \\
\hline AGFI & 0,89 & $\geq 0,90$ & $0,90-0,94$ \\
\hline NFI & 0,90 & $\geq 0,95$ & $0,90-0,94$ \\
\hline NNFI (TLI) & 0,92 & $\geq 0,95$ & $0,90-0,95$ \\
\hline CFI & 0,93 & $\geq 0,95$ & $0,05-0,08$ \\
\hline RMSEA & 0,05 & $\leq 0,05$ & \\
\hline
\end{tabular}

İlhan ve Çetin (2014: 31),

Hipotez testleri sonucunda H2 (Alg1lanan risk paylaşma niyetini anlamlı derecede negatif yönde etkilemektedir.), H3 (Güven eksikliği paylaşım niyetini anlamlı derecede negatif yönde etkilemektedir) ve H5 (Bulaşma korkusu paylaşma niyetini anlamlı derecede negatif yönde etkilemektedir) hipotezleri kabul edilmiştir. H1 (Materyalizm, paylaşma niyetini anlamlı derecede negatif yönde etkilemektedir) ve H4 (Statü tüketimi paylaşma niyetini anlamlı derecede negatif yönde etkilemektedir) hipotezleri ise reddedilmiştir (Tablo 4). 
Şekil 2: Yapısal Eşitlik Modeli

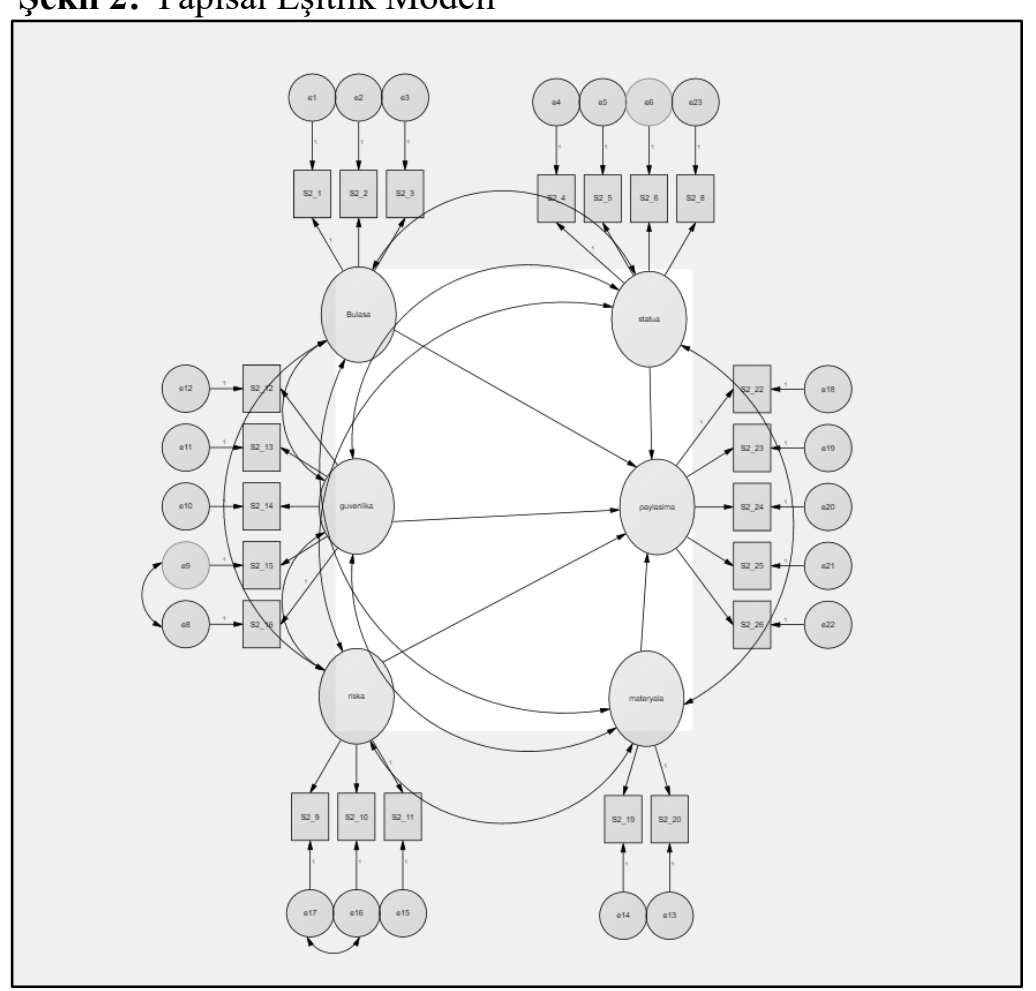

Tablo 4: Hipotez Testi Sonuçları

\begin{tabular}{|l|l|l|l|l|l|l|}
\hline Hipotezler & \multicolumn{1}{|c|}{ Yol } & Tahmin & $\begin{array}{l}\text { Standart } \\
\text { Hata }\end{array}$ & t-değeri & P Değeri & Sonuç \\
\hline $\mathrm{H}_{1}$ & Materyalizm $\rightarrow$ Paylaşma Niyeti &,- 038 & 0,168 & $-0,225$ & 0,822 & Ret \\
\hline $\mathrm{H}_{2}$ & Risk algisı $\rightarrow$ Paylaşma Niyeti & 5,202 & 1,080 & 4,818 & $\underline{0,001}$ & Kabul \\
\hline $\mathrm{H}_{3}$ & Güvenlik $\rightarrow$ Paylaşma Niyeti & $-3,873$ &, 818 & $-4,737$ & $\underline{0,001}$ & Kabul \\
\hline $\mathrm{H}_{4}$ & Statü tüketim $\rightarrow$ Paylaşma Niyeti & -0.055 & 0,167 & $-0,329$ & 0,742 & Ret \\
\hline $\mathrm{H}_{5}$ & $\begin{array}{l}\text { Bulaş korkusu } \rightarrow \text { Paylaşma } \\
\text { Niyeti }\end{array}$ & $-0,635$ & 0,233 & $-2,725$ & 0,006 & Kabul \\
\hline
\end{tabular}

Farklı paylaşım durumlarında katılımcıların paylaşma niyetleri arasında anlamlı fark olup olmadığını belirlemek amacıyla verilere sirasıyla one way anova ve bağımsız örneklem $t$ testleri uygulanmıştır (Tablo 5). One way anova testi sonucunda H6 hipotezi kabul edilmiştir. T testi sonucunda ise H6a (Kişisel ürün ve kişisel olmayan ürün paylaşım durumlarında katılımcıların paylaşma niyeti anlamlı farklılık göstermektedir) ve H6b (Paylaşım eyleminin birlikte gerçekleştiği ve gerçekleşmediği durumlara katılımcıların paylaşma niyetleri anlamlı farklılık göstermektedir) hipotezleri reddedilirken H6c (Paylaşım eylemi için ücret ödendiği ve ödenmediği durumlarda katılımcıların paylaşım niyeti farklılık göstermektedir) hipotezi kabul edilmiştir.

Tablo 5: One Way Anova ve T testi Sonuçları

\begin{tabular}{|c|l|l|l|l|}
\hline Test Edilen Hipotezler & \multicolumn{1}{|c|}{ Ort. } & \multicolumn{1}{|c|}{ Std. Sap } & \multicolumn{1}{|c|}{ F-t } & \multicolumn{1}{|c|}{ p } \\
\hline H6 & 2,5880 & 1,03070 & 16,86 & 0,000 \\
\hline \multirow{2}{*}{ H6a } & 2,5054 & 0,973 & 0,781 & 0,436 \\
\cline { 2 - 3 } & 2,3935 & 1,065 & & \\
\hline \multirow{2}{*}{ H6b } & 2,5055 &, 94915 & 0,723 & 0,471 \\
\cline { 2 - 3 } & 2,4074 & 1,04984 & & \\
\hline \multirow{2}{*}{ H6c } & 2,3558 (Ücretli) & 1,08796 & $-8,377$ & 0,000 \\
\cline { 2 - 3 } & 3,3921 (Ücretsiz) & 0,61052 & & \\
\hline
\end{tabular}




\section{Sonuç}

Paylaşım ekonomisi tüketicilerin son yıllara dek ekonominin daraldığı dönemlerde ortaya koyduğu bir tüketim davranışı iken içinde bulunduğumuz çağın sunduğu teknolojik olanaklar nedeniyle günümüzde daha yaygın ve süreklilik kazanan bir tüketim davranışı olmaya başlamaktadır. Özellikle de artan nüfus ve aşırı tüketimin doğurduğu çevresel kaygıların giderek yükselmesi paylaşım ekonomisinin önemini arttırmıştır. Bu nedenle yakın dönem çalışmalarda ağırlıklı olarak tüketicileri paylaşım ekonomisine katılmaya güdüleyen motivasyon faktörlerine odaklanıldığı görülmektedir. Paylaşım ekonomisi sisteminden, çeşitli engelleyici faktörler nedeniyle, uzak duran önemli bir tüketici kitlesi de bulunmaktadır.

Paylaşım ekonomisine katılımı engelleyen faktörlerin başında katılımcıların sisteme dâhil olma aşamasından itibaren sahip oldukları risk algıları, güvenlik kaygıları, materyalist eğilimler, statü (gösterişçi) tüketim eğilimleri ve bulaşma korkuları yer almaktadır. Risk algısı ve güvenlik katılımcıların sisteme dâhil olmak için ödeyecekleri ücret/bedel karşılığında alacakları hizmetin niteliğinden duydukları şüphe, kişisel bilgilerinin korunması ve can güvenlikleri konusunda duydukları endişeleri vb. kaygıları kapsamaktadır. Materyalist eğilimler ve statü tüketim ise tüketicilerin ürünlere sahip olma isteği ve ürünler vasıtasıyla yansıtmak istedikleri prestij ile alakalı engellerken bulaşma korkusu ise paylaşım ekonomisinden faydalanırken kullanılan hizmetlerden bulaşabilecek herhangi bir hastalık sebebini temsil etmektedir.

$\mathrm{Bu}$ çalışmada öncelikle tüketicilerin paylaşım ekonomisine katılmalarına engel olan faktörlerin hangilerinin etkili olduğunun belirlenmeye ve farklı paylaşım durumlarının paylaşma niyetine etkisini ortaya çıkartmaya çalışılmıştır. Bu amaçları gerçekleştirebilmek için paylaşım engelleri ve paylaşma niyeti faktörlerinden oluşan araştırma ölçeği farklı paylaşım durumlarını anlatan senaryolar ile (3 adet ikişerli) toplamda 6 grup ve 634 öğrenci üzerinde uygulanmıştır.

Araştırma sonucunda risk algısı, güvenlik kaygısı ve bulaşma korkusu faktörlerinin paylaşma niyeti üzerinde negatif bir etkisi olduğunu ifade eden $\mathrm{H} 2, \mathrm{H} 3$ ve $\mathrm{H} 5$ hipotezleri kabul edilmiştir. Bu sonuçlar literatürde risk algısının paylaşma niyetini negatif etkilediği sonucuna ulaşan Hajli ve Lin (2016); Pavlou vd. (2007) ve Dillahund ve Malone (2015) ile tutarlılık göstermektedir. Sonuçlar güvenlik kaygısının paylaşma niyetini negatif etkilediği yönündeki Edbring vd. (2015); Tussyadiah ve Pesonen (2018) ve So vd. (2018)'nin araştırma sonuçları ile tutarlılık göstermektedir. Diğer taraftan bulaşma korkusunun paylaşma niyeti üzerindeki etkisini açıklamaya çalışan hipotez sonucu literatürde sınırlı sayıda gerçekleştirilen çalışmalardan Lutz ve Newlands (2018) 'in araştırma sonucu ile tutarlılık gösterirken Özata vd.(2015)'nin sonucuyla farklılık göstermektedir. Bu durum bulaşma korkusunun paylaşım niyeti (davranışı) üzerindeki etkisinin netleştirilebilmesi için ilerleyen çalışmalarda daha detaylı bir şekilde araştırılması gerektiğini ortaya koymaktadır.

Materyalist eğilimlere sahip olmanın paylaşma niyeti üzerinde negatif bir etkisi olacağ1 görüşünden yola çıkarak hazırlanmış olan H1 hipotezi ise reddedilmiştir. Sonuçlar Akbar vd. (2016) ve Perfilli vd. (2019)'nin sonuçları ile farklılık göstermektedir. Bu durum ülkemizin de içinde bulunduğu kolektif toplumların paylaşım olgusuna yaklaşımlarının farklılığından kaynaklanabileceği düşüncesiyle açıklanabilir. Bu nedenle ilerleyen çalışmalarda kültür faktörünün de paylaşım engelleri arasında göz önünde bulundurularak gerçekleştirilmesi konuyla ilgili daha net sonuçlar elde edilmesine imkân sağlayacağı düşünülebilir.

Statü tüketimin paylaşma niyeti üzerinde olumsuz etkisi olduğu görüşünden yola çıarak oluşturulmuş olan H4 hipotezi de reddedilmiştir. Bu sonuç Teubner vd. (2018) Lawson, Gleim vd. (2016)'in statü tüketimin paylaşım ekonomisine dahil olmada negatif değil pozitif bir motivasyon faktörü olduğu yönündeki araştırma sonuçlarıyla tutarlılık göstermektedir. Bu sonuç tüketicilerin büyük bir çoğunluğu için değer katan ve yenilikçi bir tüketim anlayışı olması nedeniyle paylaşım ekonomisine dâhil olmanın prestijlerine zarar vermek yerine onlara saygınlık kattığı düşüncesiyle açıklanabilir. 
Son olarak farklı paylaşma durumlarının paylaşma niyeti üzerinde etkilerinin anlamlı farklılık gösterip göstermediğini belirlemek üzere farklı senaryolar ile sunulan anket verilerinin toplam ve kategorik olarak karşılaştırma analizleri yapılmıştır. Toplam verilerin analizi sonucunda tüketicilerin farklı paylaşım durumlarında paylaşım niyetlerinin farklılık gösterdiği belirlendiği için H6 hipotezi kabul edilmiştir. Kategorik olarak hangi paylaşım durumlarında paylaşım niyetinin farklı olduğunu belirlemek üzere ortaya konan alt hipotezlerin testi için yapılan analiz sonuçlarında paylaşım eylemi için ücret ödendiği ve ödenmediği durumlarda katılımcıların paylaşım niyetlerinin anlamlı farklılık gösterdikleri bulgulanmış dolayısıyla H6c hipotezi kabul edilmiştir. Diğer taraftan katılımcıların paylaşım eyleminin birlikte gerçekleştiği ve gerçekleşmediği durumlarda ve kişisel ürün ve kişisel olmayan ürün paylaşımı durumlarında paylaşma niyetleri arasında anlamlı bir farklılık gözlenemediği için H6a ve H6b hipotezleri reddedilmiştir. Bu durum katılımcıların öğrenci olması nedeniyle paylaşım niyeti üzerindeki olumlu motivasyonlardan biri olan finansal (ekonomik) motivasyon faktörünün öne çıkmasıyla açıklanabilir.

$\mathrm{Bu}$ çalı̧̧ma sonucunda paylaşım ekonomisi sistemine dâhil olmak isteyen firma yöneticilerine veya yeni girişimcilere gerek ürün ve hizmet tasarımlarında gerek pazarlama iletişimi çalışmalarında tüketicilerin risk algıları, güvenlik ve bulaşma korkularını giderecek unsurları göz önünde bulundurmaları ve ayrıca hedef kitle için farklı paylaşım durumlarında paylaşım niyetine etki eden faktörleri gözetmeleri önerilebilir.

\section{Kaynakça}

Akbar, P., Mai, R., \& Hoffmann, S. (2016). When do materialistic consumers join commercial sharing systems. Journal of Business Research, 69(10), 4215-4224.

Argo, J. J., Dahl, D. W., \& Morales, A. C. (2006). Consumer contamination: How consumers react to products touched by others. Journal of Marketing, 70(2), 81-94.

Belk, R. (2010). Possessions and self. Wiley International Encyclopedia of Marketing.

Belk, R. (2007). Why not share rather than own?. The Annals of the American Academy of Political and Social Science, 611(1), 126-140.

Belk, R. W. (1984). Three scales to measure constructs related to materialism: Reliability, validity, and relationships to measures of happiness. ACR North American Advances.

Ballús-Armet, I., Shaheen, S. A., Clonts, K., \& Weinzimmer, D. (2014). Peer-to-peer carsharing: Exploring public perception and market characteristics in the San Francisco Bay area, California. Transportation Research Record, 2416(1), 27-36.

Bauer, R. A. (1960). Consumer behavior as risk taking. Chicago, IL, 384-398.

Böcker, L., \& Meelen, T. (2017). Sharing for people, planet or profit? Analysing motivations for intended sharing economy participation. Environmental Innovation and Societal Transitions, 23, 28-39.

Botsman, R. ve Rogers, R. (2010). What's Mine Is Yours: The Rise of Collaborative Consumption, Harper-Collins, New York.

Botsman, R., \& Rogers, R. (2010). What's mine is yours. The rise of collaborative consumption.

Burns, G.L., Keortge, S., Formea, G., \& Sternberger, L.G. (1996). Revision of the Padua Inventory of obsessive compulsive disorder symptoms: Distinctions between worry, obsessions, and compulsions. Behavior Research and Therapy, 34, 163-173. 
Demirer, D., \& Hassan, A. (2016). Değiş tokuş ve kiralama uygulamalarının konaklama işletmeleri üzerindeki olas1 etkileri. Anatolia: Turizm Araştırmalanı Dergisi, 27(1), 43-61.

Dillahunt, T. R., \& Malone, A. R. (2015, April). The promise of the sharing economy among disadvantaged communities. In Proceedings of the 33rd Annual ACM Conference on Human Factors in Computing Systems (pp. 2285-2294). ACM.

Ersoy-Quadir, S. (2012). An analysis of some of the factors behind materialism among university students in Turkey. Journal of adult development, 19(2), 79-87.

Dimoka, A. (2010). What does the brain tell us about trust and distrust? Evidence from a functional neuroimaging study. Mis Quarterly, 373-396.

Eastman, J. K., Goldsmith, R. E., \& Flynn, L. R. (1999). Status consumption in consumer behavior: Scale development and validation. Journal of marketing theory and practice, 7(3), 41-52.

Edbring, E. G., Lehner, M., \& Mont, O. (2016). Exploring consumer attitudes to alternative models of consumption: motivations and barriers. Journal of Cleaner Production, 123, 5-15.

Edbring, E. G., Lehner, M., \& Mont, O. (2016). Exploring consumer attitudes to alternative models of consumption: motivations and barriers. Journal of Cleaner Production, 123, 5-15.

Ertz, M., Durif, F., \& Arcand, M. (2016). An Analysis of the Origins of Collaborative Consumption and Its Implications for Marketing.

Garson, D. (2012). Testing statistical assumptions. Statistical Associates Publishing-Blue Book Series, Asheboro

Gazzola, P., Vătămănescu, E. M., Andrei, A. G., \& Marrapodi, C. (2019). Users' motivations to participate in the sharing economy: Moving from profits toward sustainable development. Corporate Social Responsibility and Environmental Management, 26(4), 741-751.

Goldsmith, R. E., \& Clark, R. A. (2012). Materialism, status consumption, and consumer independence. The Journal of social psychology, 152(1), 43-60.

Griskevicius, V., \& Kenrick, D. T. (2013). Fundamental motives: How evolutionary needs influence consumer behavior. Journal of Consumer Psychology, 23(3), 372-386.

Güllülü, U., Ünal S., \& Bilgili, B. (2010). Kendini Gösterim Ve Kişilerarası Etkileşimin Gösterişçi Tüketim Üzerindeki Etkilerini Belirlemeye Yönelik Bir Araştırma. Hacettepe Üniversitesi İktisadi ve İdari Bilimler Fakültesi Dergisi, 28(1), 105-139.

Hajli, N., \& Lin, X. (2016). Exploring the security of information sharing on social networking sites: The role of perceived control of information. Journal of Business Ethics, 133(1), 111-123.

Hamari, J., Sjöklint, M., \& Ukkonen, A. (2016). The sharing economy: Why people participate in collaborative consumption. Journal of the Association for Information Science and Technology, 67(9), 2047-2059.

Hawlitschek, F., Teubner, T., \& Gimpel, H. (2018). Consumer motives for peer-to-peer sharing. Journal of Cleaner Production, 204, 144-157.

Hong, S. J. (2017). Assessing economic value of reducing perceived risk in the sharing economy: the case of ride-sharing services.

Hwang, J., \& Griffiths, M. A. (2017). Share more, drive less: Millennials value perception and behavioral intent in using collaborative consumption services. Journal of Consumer Marketing, 34(2), 132-146. 
İlhan, M., \& Çetin, B. (2014). LISREL ve AMOS programları kullanılarak gerçekleştirilen yapısal eşitlik modeli (yem) analizlerine ilişkin sonuçların karşılaştırılması. Eğitimde ve Psikolojide Ölçme ve Değerlendirme Dergisi, 5(2), 26-42.

Kalaycı, Ş. (2014). “SPSS Uygulamalı Çok Değişkenli İstatistik Teknikleri”, Ankara: Asil Yayınları

Kalaycı, Ş. (Ed.), (2006). SPSS uygulamalı çok değişkenli istatistik teknikleri (2. Baskı). Ankara: Asil Yayın Dağıtım.

Karaca, Ş. (2019). Materyalist Eğilimlerin Anlık Satın Alma Davranışına Etkisinin İncelenmesi: Üniversite Öğrencilerine Yönelik Bir Çalışma. Third Sector Social Economic Review, 54(1), 243-260.

Kurtuluş, K. (2010). “Araştırma Yöntemleri”, İstanbul: Türkmen Kitabevi

Lamberton, C. P., \& Rose, R. L. (2012). When is ours better than mine? A framework for understanding and altering participation in commercial sharing systems. Journal of Marketing, 76(4), 109-125.

Larsen, V., Sirgy, J.M. and Wright, N.D. (1999),"Materialism: The construct, measures, antecedents, and consequences",Academy of Marketing Studies Journal, Vol. 3,No. 2, pp. 78-110.

Lawson, S. J., Gleim, M. R., Perren, R., \& Hwang, J. (2016). Freedom from ownership: An exploration of access-based consumption. Journal of Business Research, 69(8), 2615-2623.

Lee, J., Kim, S., \& Ham, C. D. (2016). A double-edged sword? Predicting consumers' attitudes toward and sharing intention of native advertising on social media. American Behavioral Scientist, 60(12), 1425-1441.

Lee, Z. W., Chan, T. K., Balaji, M. S., \& Chong, A. Y. L. (2018). Why people participate in the sharing economy: an empirical investigation of Uber. Internet Research, 28(3), 829-850.

Lim, N. (2003). Consumers' perceived risk: sources versus consequences. Electronic Commerce Research and Applications, 2(3), 216-228.

Lindblom, A., Lindblom, T., \& Wechtler, H. (2018). Collaborative consumption as C2C trading: Analyzing the effects of materialism and price consciousness. Journal of Retailing and Consumer Services, 44, 244-252.

Lutz, C., \& Newlands, G. (2018). Consumer segmentation within the sharing economy: The case of Airbnb. Journal of Business Research, 88, 187-196.

Mahadevan, R. (2018). Examination of motivations and attitudes of peer-to-peer users in the accommodation sharing economy. Journal of Hospitality Marketing \& Management, 27(6), 679-692.

Manchiraju, S., \& Krizan, Z. (2015). What is materialism? Testing two dominant perspectives on materialism in the marketing literature. Management \& Marketing, 10(2), 89-102.

Mittendorf, C., \& Ostermann, U. (2017). Private vs. business customers in the sharing economy-The implications of trust, perceived risk, and social motives on Airbnb.

Morgan, G. A., Leech, N. L., Gloeckner, G. W., \& Barrett, K. C. (2012). IBM SPSS for introductory statistics: Use and interpretation. Routledge.

Möhlmann, M. (2015). Collaborative consumption: determinants of satisfaction and the likelihood of using a sharing economy option again. Journal of Consumer Behaviour, 14(3), 193-207. 
Neunhoeffer, F., \& Teubner, T. (2018). Between enthusiasm and refusal: A cluster analysis on consumer types and attitudes towards peer-to-peer sharing. Journal of Consumer Behaviour, 17(2), 221-236.

O'cass, A., \& McEwen, H. (2004). Exploring consumer status and conspicuous consumption. Journal of Consumer Behaviour: An International Research Review, 4(1), 25-39.

Ozanne, L. K., \& Ballantine, P. W. (2010). Sharing as a form of anti-consumption? An examination of toy library users. Journal of Consumer Behaviour, 9(6), 485-498.

Özata, F. Z., Er, İ., Öztürk, S. A., \& Ağlargöz, F. (2015). Ortak Tüketememek: Paylaşma Davranışını Engelleyen Faktörlerin Belirlenmesi Üzerine Bir Araştırma. Ulusal Pazarlama Kongresi Bildiriler Kitab1, 2, 625-626.

Öztürk, S. A., \& Öztay, H. (2019) Yerli Ve Yabancı Hızlı Moda Markası Satın Alma Niyetinde Etnosentrizm, Materyalizm Ve Dış Görünüş Kaygısının Etkisi. Anadolu Üniversitesi İktisadi ve İdari Bilimler Fakültesi Dergisi, 20(1), 14-29.

Pavlou, P. A., Liang, H., \& Xue, Y. (2007). Understanding and mitigating uncertainty in online exchange relationships: A principal-agent perspective. MIS quarterly, 105-136.

Perfili, M., Parente, S., Grimaldi, M., \& Morales-Alonso, G. (2019). A Study on Consumer Behaviour in the Sharing Economy. In Engineering Digital Transformation (pp. 79-86). Springer, Cham.

Rachman, S. (2004). Fear of contamination. Behaviour Research and Therapy, 42(11), 1227-1255.

Richins, M. L., \& Dawson, S. (1992). A consumer values orientation for materialism and its measurement: Scale development and validation. Journal of consumer research, 19(3), 303316.

Schor, J. B., \& Fitzmaurice, C. J. (2015). 26. Collaborating and connecting: the emergence of the sharing economy. Handbook of research on sustainable consumption, 410.

Sekaran, U. (2003). "Research Methods For Business: A Skill Building Approach”, New York: John Wiley \& Sons, Inc.

So, K. K. F., Oh, H., \& Min, S. (2018). Motivations and constraints of Airbnb consumers: Findings from a mixed-methods approach. Tourism Management, 67, 224-236.

Srikant, M. (2013). Materialism in consumer behavior and marketing: a review. Management \& Marketing, 8(2), 329.

Sundararajan, A. (2014) 'Peer-to-peer businesses and the sharing (collaborative) economy: Overview, economic effects, and regulatory issues', Written testimony for the hearing titled The Power of Connection: Peer to Peer Businesses.

Teubner, T., Hawlitschek, F., 2018. The economics of peer-to-peer online sharing, in: Albinsson, P., Perera, Y. (Eds.), The Sharing Economy: Possibilities, Challenges, and the Way Forward. Praeger Publishing, pp. 129-156

Tosun, N. B., \& Cesur, D. K. Tüketimin Paranormali: Gösterişçi Tüketim Ve Paranormal İnanç İlişkisi1. Öneri Dergisi, 13(49), 167-186.

Tussyadiah, I. P., \& Pesonen, J. (2018). Drivers and barriers of peer-to-peer accommodation stayan exploratory study with American and Finnish travellers. Current Issues in Tourism, 21(6), 703-720. 
Yakın V., Kacar İ. A., Ay İ. C., (2017) Sharing Economy: Why the Turkish consumers use Airbnb?, Journal of Marketing and Consumer Behaviour in Emerging Markets 2(6).

Yakın, Volkan (2018). "Paylaşım Ekonomisi A'dan Z'ye Tüm Boyutlarıyla”. Paylaşım Ekonomisi: Tanımı ve Sınıflandırmaları. Ed. C. Ay, V. Yakın, A.İ. Kacar. Ankara: Akademisyen Kitabevi: $19-30$

Zhu, G., So, K. K. F., \& Hudson, S. (2017). Inside the sharing economy: understanding consumer motivations behind the adoption of mobile applications. International Journal of Contemporary Hospitality Management, 29(9), 2218-2239. 